\title{
MEMBANGUN BUDAYA SEKOLAH MELALUI PENGEMBANGAN PENDIDIKAN AGAMA ISLAM DI SMA NEGERI 3 PALU
}

\author{
Elya $^{1)}$ \\ e-mail: elya@iainpalu.ac.id \\ ${ }^{1}$ Dosen Fakultas Tarbiyah dan Ilmu Keguruan IAIN Palu
}

\begin{abstract}
This study discusses how to build a school culture through the development of Islamic religious education in SMA Negeri 3 Palu. This study aims to develop and preserve the school culture (school culture) that is characterized and strong. The specific target achieved is how all school members can participate and apply religious culture, work team culture and leadership culture in interacting both in the classroom and outside the classroom with various programs that have been arranged by the school. The research method used is descriptive qualitative, data obtained through observations, interviews and documentation, location photos and behavior of all citizens of SMA Negeri 3 Palu. Data were analyzed with the Hubberman model which included data collection, data analysis, data verification and data reduction. The results showed that there were three components of school culture developed in SMA Negeri 3 Palu, namely: first, religious culture, namely culture instilling systematic behavior and manners in practicing their respective religions so as to form personalities and good attitudes (akhlaqul Karimah) and discipline in various matters, both in the classroom and outside the classroom. Second, the culture of team work is to instill a sense of togetherness and social sense through joint activities. Form of School Orientation (MOS) activities, industry visits, Parents Day, social service, foster friends, Sport and Art, Museum Visits, Performances of Art, Comparative Studies, Ekskul, Labs Channel, Labs TV, Labs Care, Student Release, School Uniforms, School Magazines, Potency Mapping. Third, the culture of leadership (Leadership), is to instill leadership and leadership from an early age. Form of Activity, Career Day; culture of hard work, smart and sincere, Creative culture; Independent and responsible, culture of discipline, cross-struggle student council, public lectures, flag ceremony, Friday Morning Sports, student leadership studies, LKMS, OSIS. With the motto agreed by the school for example being creative and achieving, it will make the school superior and quality. The implication of this research is that the school culture must remain strong and maintained, even the school is ready to share the experience of the achievements of the national high school achieved, to other schools in Central Sulawesi.
\end{abstract}

Keywords: Building School Culture, Islamic Education 


\section{PENDAHULUAN}

Salah satu keunggulan sekolah adalah memiliki budaya sekolah (school culture) yang kokoh, dan tetap eksis.Deal dan Peterson, mengatakan budaya sekolah adalah sekumpulan nilai yang melandasi perilaku, tradisi, kebiasaan ${ }^{1}$, keseharian, dan simbol-simbol yang dipraktekkan oleh kepala sekolah, guru, petugas administrasi, siswa, dan masyarakat sekitar sekolah. Budaya sekolah merupakan ciri khas, karakter atau watak, dan citra sekolah tersebut di masyarakat luas. $^{2}$

Sekolah harus mempunyai misi menciptakan budaya berkarakter yang menantang dan menyenangkan, adil, kreatif, terintegratif, dan dedikatif terhadap pencapaian visi, menghasilkan lulusan yang berkualitas tinggi dalam perkembangan intelektualnya dan mempunyai karakter takwa, jujur, kreatif, mampu menjadi teladan, bekerja keras, toleran dan cakap dalam memimpin, serta menjawab tantangan akan kebutuhan pengembangan sumber daya manusia yang dapat berperan dalam perkembangan iptek dan berlandaskan imtak.

Budaya sekolah adalah hasil penggabungan perilaku orang-orang yang terlibat dalam sekolah tersebut. Terbentuknya budaya sekolah dipengaruhi oleh banyak faktor, antara lain antusias guru dalam mengajar dan penguasaan materi dengan segala model pembelajaran, patuh pada aturan, berdisiplin tinggi, berdisiplin tinggi dan gaya kepemimpinan kepala sekolah. ${ }^{33}$

Pendidikan agama Islam sebagai upaya mendidikan agama Islam atau ajaran Islam dan nilai-nilainya, agar menjadi way of life (pandangan dan sikap hidup) sesorang yang berwujud segenap kegiatan yang dilakukan seseorang untuk membantu seseorang atau kelompok peserta didik dalam menanamkan dan/atau menumbuh kembangkan ajaran Islam dan nilai-nilainya untuk dijadiakan sebagai pandangan hidupnya, yang diwujudkan dalam sikap hidup dan dikembangkan dalam keterampilan hidup sehari-hari. ${ }^{4}$ Selain itu Pendidikan Agama Islam bertujuan untuk membentuk pribadi muslim seutuhnya, mengembangkan seluruh potensi manusia baik yang berbentuk jasmaniah maupun rohaniyah. ${ }^{5}$

Menurut Komaruddin Hidayat pendidikan agama lebih berorientasi pada belajar tentang agama, yang mengetahui nilai-nilai ajaran agama, dan memahami

${ }^{1}$ Muhaimin, Nuansa Baru Pendidikan Islam, (Jakarta : PT. Raja Grafindo Persada, 2006), 124

${ }^{2}$ Muhaimin, Nuansa Baru Pendidikan Islam,...... 133

${ }^{3}$ Kompri, Manajemen Sekolah: Teori dan Praktek,( Bandung: Alfabeta, 2014), 263

${ }^{4}$ Muhaimin, Pengembangan Kurikulum Pendidikan Agama Islam di Sekolah Madrasah, dan Perguruan Tinggi, (Jakarta : PT Raja Grafindo Perasa, 2005), 8

${ }^{5}$ Haydar Putra daulay, Pemberdayaan pendidikan Islam di Indonesia, (Cet : I, Jakarta : PT Rineka Cipta, 2009), 6 
ajaran bukan hanya sekedar mengetahui saja hingga hasilnya banyak orang tata perilakunya tidak relevan dengan nilai-nilai ajaran agama yang diketahuinya. ${ }^{6}$

Akhir-akhir ini, seringkali terjadi perkelahian antar pelajar atau tauran, tindak kekerasan guru terhadap siswa, dan penganiayaan siswa kelas tinggi terhadap adik kelasnya.Berbagai aksi ini seringkali ditujukan pada kegagalan pendidikan agama dalam membentuk kepribadian peserta didik.Untuk itu, pendidikan agama perlu dikembangkan sebagai budaya sekolah. Karena budaya sekolah merupakan perpaduan nilai-nilai, sikap dan perilaku pihak-pihak yang terkait dengan sekolah atau perilaku serta kebiasaan-kebiasaan yang dilakukan oleh warga sekolah secara konsisten.

Pengembangan Pendidikan Agama Islam tidak cukup hanya dengan mengembangkan pembelajaran di kelas dalam bentuk peningkatan kualitas dan penambahan jam pembelajaran, tetapi bagaimana mengembangkan Pendidikan Agama Islam dalam membangun budaya sekolah. Hal ini merupakan langkah strategis yang dapat dilakukan sekolah dengan jalan meningkatkan peran-peran kepemimpinan sekolah dan kesadaran warga dan komunitas sekolah untuk pewujudan budaya di sekolah.Komitmen dan kerjasama secara sinergis diantara warga sekolah dan dukungan orang tua menjadi kunci keberhasilan dalam mewujudkan budaya sekolah. ${ }^{7}$

Sehubungan dengan uraian di atas, penulis merasa tertarik untuk kemudian membuktikan secara empirik dengan melakukan penelitian langsung di lapangan mengenai Pentingnya Membangun Budaya Sekolah Melalui Pengembangan Pendidikan Agama Islam (PAI) Pada Peserta Didik di SMA Negeri 3 Palu, sebagai sekolah favorit yangmenerapkan sistem pengembangan budaya sekolah yang terintegrasi dan terimplementasi dalam proses pembelajaran. Sekolah tersebut juga telah melakukan inovasi-inovasi kegiatan budaya sekolah dan terinventarisasikannya budaya sekolah yang sesuai dengan nilai-nilai lokal, nasional, dan internasional.

Semuanya itu telah menyatu ke dalam kegiatan akademik dan kegiatan kesiswaan melalui kegiatan yang bersifat intrakurikuler dan ekstrakurikuler. Namun, ditengah keberhasilan sekolah tersebut masih terdapat berbagai problem dalam proses membangun budaya sekolah. Seperti masih adanya siswa yang bolos dan tidur di kelas walaupun pendidikan agama yang diterapkan diupayakan untuk membangun karakter.Olehnya itu penulis tertarik untuk mengetahui lebih jauh penyebab dan hambatan-hambatan yang dihadapi oleh sekolah tersebut dalam membangun budaya sekolah yang dikembangkan melalui pengembangan pendidikan agama Islam di sekolah tersebut.

\section{METODE}

Metode penelitian yang digunakan adalah deskriptif kualitatif, data yang diperoleh melalui hasil observasi, wawancara dan dokumentasi, foto lokasi dan perilaku seluruh warga sekolah SMA Negeri 3 Palu. Data dianalisis dengan model

${ }^{6}$ Muhaimin,Nuansa Baru Pendidikan Islam.,... 25

${ }^{7}$ Wijaya Kusuma, Budaya-sekolah,http://education-mantap. Blogspot.com(on-line) diakses pada tanggal 28 Mei 2019 
Matthew B. Miles dan Hubberman. Digunakan pendekatan kualitatif dalam hal ini karena fokus penelitian yang bersifat mendeskripsikan pengembangan budaya sekolah dan peran pendidikan agama Islam dalam membangun kultur budaya yang religius dikalangan warga sekolah dalam berinteraksi baik di dalam kelas maupun di luar kelas. Penelitian yang sifatnya deskriftif menurut Suharsimi Arikunto, lebih tepat apabila menggunakan pendekatan kualitatif. Peneliti dalam memperoleh data di lapangan menggunakan teknik observasi, wawancara dan dokumentasi. Ada beberapa hal yang diobservasi perilaku warga sekolah dalam berinteraksi, wawancara kepala sekolah, wakasek, dewan guru, tata usaha, clening servis dan satpam sekolah. Penelitian secara kualitatif bertujuan agar penelitian benar-benar memperoleh data yang valid, sehingga dapat memepertahankan kebenaran serta keabsahan dari hasil penelitian.

Lokasi penelitian yang dimaksudkan dalam penelitian ini di SMA Negeri 3 Palu Kelurahan Birobuli Selatan Kota Palu. Peneliti memilih lokasi SMA Negeri 3 Palu karena sekolah tersebut menjadi sekolah favorit masyarakat Kota Palu dan warga yang ada di sekolah tersebut multi etnis, multi kultur dan multi religius. Peneliti tertarik mendalami perkembangan budaya sekolah yang cukup maju, berkarakter dan banyak prestasi yang telah diraih baik tingkat lokal, nasional maupun internasional. Lebih lanjut menurut Burhan Bugin ada dua jenis sumber data yang biasanya digunakan dalam penelitian kualitatif yaitu data primer dan data sekunder. Dalam tekinik pengumpulan data peneliti melakukan dengan menghimpun data yang relevan dari sejumlah dokumen resmi dan arsip penting yang dapat menunjang kelengkapan penelitian seperti transkrip wawancara, tape recorder dan kamera sebagai bukti bahwa peneliti berada di lokasi penelitian.

Setelah sejumlah data dan keterangan berhasil dikumpulkan, maka langkah selanjutnya adalah menganalisis data dengan beberapa teknik. Metode yang digunakan adalah sebagai berikut :

1. Reduksi data, adalah menganalisis data dengan cara memilih serta menentukan data dan keterangan yang dianggap relevan dengan pembahasan ini. Reduksi data diartikan sebagai proses pemilihan, pemusatan perhatian pada penyederhanaan, pengabstrakan dan transformasi data-data "kasar" yang muncul dari catatancatatan tertulis dilapangan, sebagaimana kita ketahui reduksi data berlangsung terus-menerus selama obyek berorientasi kualitatif berlangsung. ${ }^{8}$

2. Penyajian data, adalah setelah sejumlah data selesai dirangkum, maka langkah selanjutnya adalah menyajikan data tersebut ke dalam pembahasan. Bentuk penyajiannya sederhana tanpa harus membutuhkan keterangan lain.

3. Verifikasi data, adalah menganalisis data dan keterangan dengan cara melakukan evaluasi terhadap sejumlah data yang benar-benar validitas dan reliabilitas (hal yang dapat dipercaya keabsahannya). Bentuk analisis data ini adalah membuktikan kebenaran, apakah data yang diperoleh benar-benar otentik (asli) ataukah memerlukan klarifikasi (penjelasan). Untuk menetapkan keabsahan data diperlukan tekhnik pemeriksaan.

\footnotetext{
${ }^{8}$ Mattew B. Milles, Quantitatif Data Analisis. Diterjemahkan oleh Tjep Rohandi,analisis data kualitatif, (Jakarta; UI Press, 1992). 16
} 
Pelaksanaan teknik pemeriksaan didasarkan pada sejumlah kriteria keabsahan data yang bisa digunakan yaitu derajat kepercayaan (credibility), keteralihan (transferability), kebergantungan (dependability), dan kepastian (confirmability) 9 Pengecekan keabsahan data dilakukan dengan tujuan untuk memperoleh data yang akurat, pengecekan keabsahan data dilakukan dengan cara mengoreksi data satu persatu agar dapat diketahui kesalahan-kesalahan yang ada, kemudian akan disempumakan lebih lanjut. Selanjutnya untuk mengecek keabsahan data yang diperoleh maka dilakukan melalui cara triangulasi yaitu teknik pemeriksaan keabsahan data yang memanfaatkan sesuatu yang lain, diluar data itu untuk keperluan pengecekan atau sebagai pembandingan terhadap data itu.

\section{HASIL PENELITIAN}

Budaya dan iklim sekolah yang kondusif sangat penting agar peserta didik merasa tenang, aman dan nyaman berada sekolahnya, begitupun pendidik merasakan dirinya dihargai, dan agar orang tua serta masyarakat merasa dirinya diterima dan dilibatkan oleh warga sekolah. Hal ini dapat terjadi melalui penciptaan norma dan kebiasaan yang positif, hubungan dan kerja sama yang harmonis yang didasari oleh sikap saling menghargai satu sama lain.

Sebagaimana yang telah dikemukakan sebelumnya bahwa pembahasan pada penelitian ini yang menyangkut budaya sekolah dibatasi pada budaya sekolah yang perlu dibangun dan dikembangkan melalui pengembangan pendidikan agama Islam (PAI) yaitu budaya religius, budaya kerja sama, dan budaya kepemimpina yang selanjutnya bagaimana cara membangun buaya tersebut. Mengingat begitu luasnya permasalahan dalam membahas budaya sekolah.

Dalam mewujudkan budaya sekolah yang sejalan dengan nilai-nilai pendidikan agama Islam, tidak terlepas dari peran para penggerak kehidupan keagamaan di sekolah tersebut yang berusaha melakukan aksi pembudayaan agama di sekolah. Hal ini sesuai dengan pernyataan guru Pendidikan Agama Islam, yaitu:

Budaya sekolah yang dibangun di SMA 3 ini tentunya atas kerjasama semua pihak khususunya guru Pendidikan Agama Islam terhadap semua warga sekolah.Apalagi kepala sekolah mempunyai pengaruh besar dalam menanamkan nilai-nilai agama Islam. Hal ini bisa dilihat dari kehidupan keseharian peserta didik yang berpenampilan dan berperilaku yang agamis, misalnya pada peserta didik putri memakai rok panjang sampai mata kaki, hal ini karena di SMA Negeri 3 Palu mengedepankan pemantapan Agama untuk pembangunan karakter. ${ }^{10}$

Berdasarkan hasil wawancara tersebut dapat diketahui bahwa budaya sekolah yang dikembangkan di SMA Negeri 3 Palu, keseluruhannya merupakan pendidikan karakter, jadi bukan hanya semata-mata pengembangan kognitif tetapi bagaimana kemantapan kognitif siswa berjalan diiringi dengan nilai afektif dan psikomotorik yang mantap, dan hal inilah perlu adanya pembinaan melalui pengembangan Pendidikan Agama Islam.

${ }^{9}$ Lexy J. Moleong, Metodologi Penelitian Kualitatif, 173.

${ }^{10} \mathrm{Hj}$. Wati, Guru Pendidikan Agama Islam SMA N 3 Palu, "Wawancara", Taman Literasi, tanggal 20 September 2019 
Mengacu pada budaya sekolah yang dibangun melalui peran pengembangan pendidikan agama Islam di SMA Negeri 3 Palu sesuai dengan sasaran penelitian ini dapat dibedakan menjadi:

1. Budaya Religius

a). Budaya Salam

Budaya salam yang diterapkan di SMA Negeri 3 Palu ditujukan terhadap semua warga warga sekolah khususnya peserta didik, baik itu muslim maupun non muslim. Salam sudah menjadi satu hal yang diyakini bagian dari satu kewajiban. Bahkan kebiasaan keseharian di sekolah kini terbawa sampai di lingkungan luar peserta didik. Hal ini tidak lepas dari peran guru pendidikan Islam yang memberikan pemahaman bahwa menebarkan salam adalah salah satu dari kewajiban setiap muslim, sehingga dengan pemahaman yang demikian dalam keseharian peserta didik membudayakan salam sudah mereka anggap sebagai kewajiban yang sudah melekat dalam pribadi masing-masing. 11

b) Shalat Dhua' dan baca doa sebelum belajar

Budaya baca doa dilakukan tiap apel pagi, saat mulai pelajaran dan ketika akan pulang sekolah. Hal ini dilakukukan sebagai upaya menanamkan kepada peserta didik bahwa dalam setiap usaha yang diiringi dengan doa maka hasilnya akan lebih terasa manfaatnya dan lebih membawa berkah.

c) Pengajian rutin dan Tadarrus Al-Qur'an

Kegiatan pengajian rutin dilaksanakan setiap hari kamis dan minggu yang melibatkan para dewan guru sebagai penanggung jawabnya khususnya guru pendidikan agama Islam. Hal ini sesuai dengan penuturan guru pendidikan agama Islam bahwa sebagai penanggung jawab langsung kegiatan religius maka pengajian rutin ini merupakan kesempatan yang tepat untuk mengajarkan kepada peserta didik fadhilah-fadhilah surah Al-Qur'an yang dibaca, dan yang kami baca secara continue adalah surah Ar-Rahman, Al-Kahfi, Yasin, Al-Mulk dan dzikir-dzikir penuntun kehidupan serta di dalamnya diajarkan berbagai niat shalat dan tata cara shalat, selain itu dari kegiatan pengajian rutin peserta didik pun terlatih berorganisasi. ${ }^{1212}$

d) Shalat Zuhur Berjama'ah

Sebagaimana penuturan wakasek Kurikulum, bahwa shalat zuhur berjama'ah merupakan kegiatan harian yang merupakan suatu kewajiban.Maka setiap masuk waktu zuhur peserta didik akan segera menuju mushallah untuk elaksanakan sholat berja'mah. Dan shalat berjama'ah tersebut banyak dimotori langsung oleh Pembina pendidikan agama Islam baik yang perempuan maupun Pembina laki-laki yang langsung menjadi imam shalat.

e) Kegiatan Bina Taqwa Osis

11 Wati, Guru Pendidikan Agama Islam SMA N 3 Palu, "Wawancara",Taman Literasi, tanggal 20 September 2019

${ }^{12}$ Minarni, Guru Pendidikan Agama Islam SMA N 3 Palu, "Wawancara”, Gedung Perpustakaan, tanggal 23 September 2019 
Dalam hal ini wakasek kurikum menuturkan bahwa: "Bina takwa, yang sebelumnya disebut pesantren kilat tetapi karena ada tiga macam agama maka namanya pun disesuaikan berubah menjadi bina takwa yang mana pembinaan tersebut disesuaikan pula dengan tempat ibadahnya masing-masing. Adapun materi yang bersifat umum yang menyangkut kepemimpinan, bagaimana bertoleransi, semua itu kami kumpulkan di satu aula, itulah sebabnya diberi nama bina takwa. ${ }^{13}$

f) Kegiatan Bulan Ramadhan

Kegiatan bulan ramadhan yang menjadi rutinitas tahunan meliputi shalat

taraweh dan buka puasa bersama yang diisi dengan ceramah agama.Pemantapan agama lebih dipermantap di bulan ini, hakikat puasa diharapkan bisa membangun dan memantapkan karakter peserta didik lebih baik lagi.

g) Melaksanakan Qurban

Tak ketinggalan SMA Negeri 3 Palu aktif melaksanakan penyembelihan hewan qurban setiap hari raya Idul Adha. Tentunya atas kerja sama dari semua warga sekolah.

Sejalan dengan ungakapan tersebut, wakasek kurikulum lebih mempertegas saat diwawancarai mengenai bagaimana membangun budaya religus melalui peran pengembangan Pendidikan Agama Islam, yaitu:

Di SMA Negeri 3 Palu pembinaan pendidikan agama Islam cukup eksis, dengan diadakan shalat berjamaah untuk pembinaan keseharian bagi siswa yang beragama Islam sesuai dengan syari'at Islam. Adapun terhadap agama lain kami pun melakukan pembinaan secara merata sesuai dengan ajaran agamanya dan tempat ibadahnya masing- masing ${ }^{14}$.

Dari pernyataan wakasek tersebut terlihat jelas bahwa budaya religius di SMA Negeri 3 merupakan bagian dari program peningkatan iman dan taqwa siswa terhadap Tuhan Yang Maha Esa danpemahaman kepada peserta didik tentang pentingnya kegiatan keagamaan,dengan rencana kegiatan seperti yang disebutkan di atas

Lain halnya dengan Pembina pendidikan Agama Islam di SMA Negeri 3 Palu mengkatakan:

Dalam membangun budaya religius terhadap peserta didik,semua itu kembali kepada individu masing-masing, karena dalam hal ini pendidikan karaktek yang ditanamkan di sekolah melalui pengembangan pendidikan Agama Islam tidak berhenti pada wilayah itu saja, yang paling penting adalah bagaimana pendidikan agama dalam lingkungan keluarga dan masyarakat harus selalu menjadi

\footnotetext{
${ }^{13}$ Halimatang, wakasek kurikulum SMA Negeri 3 Palu, "Wawancara” Ruang Wakasek Kurikulum, tanggal 23 September 2019

${ }^{14}$ Halimatang, wakasek kurikulum SMA Negeri 3 Palu, "Wawancara" Ruang Wakasek Kurikulum, tanggal 23 September 2019
} 
factor fundamental yang berpengaruh pada pertumbuhan dan perkembangan pendidikan keagamaan anak. ${ }^{15}$

Budaya-budaya religius yang dibangun di SMA Negeri 3 tersebut dibangun melalui pengembangan Pendidikan Agama Islam maksudnya adalah bahwa ruang yang lebih luas bagi mata pelajaran Pendidikan Agama Islam yang hanya dua atau tiga jam perminggu agar merata pengaruhnya bagi karakter siswa,baik di dalam maupun di luar sekolah serta bagaimana menjadikan pendidikan agama Islam lebih baik. Hal ini sesuai dengan penuturan guru pendidikan agama Islam yaitu:

Budaya-budaya religius yang dilaksanakan di sekolah ini tentunya mengajarkan sekaligus sebagai pola pendidikan yang lebih religi ilmu tambahan dari materi-materi pendidikan agama Islam yang sesuai dengan kurikulum. Seperti yasinan yang kami laksanakan tiap malam jum'at dan ceramah agama setiap hari minggu disitulah kami mengajarkan apa saja faedah dan manfaat yang terkandung di dalamnya, sehingga siswa bukan hanya sekedar mempraktekannya tetapi yang terpenting mengetahui manfaat dan sumber dari apa yang mereka kerjakan. Dengan begitu jadilah mereka orang-orang yang bermanfaat sebagaimana hadits Rasulullah sebaik-baiknya manusia adalah yang bermanfaat terhadap yang yang lain. ${ }^{16}$

Dari hasil wawancara diatas dapat dilihat bahwa SMA Negeri 3 Palu mengedepankan pembinaan karaktek dalam proses pembelajaran yang semua pembinaan itu telah sejalan bahkan sesuai dengan pengembangan pendidikan agama Islam. Pola pembinaan budaya religius terhadap peserta didik tersebut pada akhirnya akan merembes pada penghayatan psikologis peserta didik yang pada gilirannya membentuk pola, nilai, sikap, kebiasaan dan perilaku.

Tuntunan Karakter Siswa SMA Negeri 3 Palu merupakan keunggulan dari SMA Negeri 3 Palu yang jelas memberikan pengaruh besar terhadap semua warga sekolah. Hal ini karena SMA Negeri 3 Palu memberlakukan delapan Mental Sehat siswa siswi SMA Negeri 3 Palu, sebagaimana penuturan wakasek kesiswaan:

Delapan mental sehat SMA Negeri Palu yaitu 1) Dapat menyesuaikan diri dengan lingkungan, 2).merasa puas dengan hasil karya sendiri, 3).lebih senang member dari pada menerima, 4). Suka membantu dan menyenangkan orang tua, 5).Dapat mengambil hikmah dari kegagalan, 6).Dapat mengambil penyelesaian secara konstruktif, 7).Relative bebas dari ketegangan dan keresahan, 8).Mengembangkan sikap toleransi antar umat beragama. ${ }^{17}$

\footnotetext{
${ }^{15}$ Mukaddas, Guru Matematika/ Pembina pendidikan agama Islam SMA Negeri 3 Palu, "Wawancara”, Ruang Perpustakaan, tanggal 23 September 2019

16 .Minarni, Guru Pendidikan Agama Islam SMANegeri 3 Palu, "Wawancara", Gedung Perpustakaan, tanggal 23 September 2019

${ }^{17}$ Haeruddin Lamunte, Wakasek Kesiswaan SMA Negeri Palu, "Wawancara", Ruang Wakasek, tanggal 26 September 2019
} 
Dari keterangan tersebut dapatlah diketahui bahwa dengan adanya pendidikan karakter dapat diaplikasikan dalam interaksi peserta didik yang mempunyai mental sehat dilingkungan sekolah dan akan semakin mudah pula untuk membangun karakter peserta didik apalagi mereka yang telah terbiasa mempraktekan delapan mental tersebut. Dengan begitu budaya sekolah yang dikembangkan melalui peran pendidikan agama Islam akan merata pengaruhnya, selain itu juga akan mudah memberikan pembinaan-pembinaan keislaman diluar materi kelas.Mengajarkan bahkan lebih kepada proses mendidik mengenai subtansi dari ajaran dan pengamalan agama Islam tentang manfaat yang dapat diperoleh yang kemudian terimplementasikan dalam kehidupan sehari-hari baik dalam kegiatan religious dan kegiatan lainnya.

2. Budaya Team work (kerja sama)

Budaya kerja sama yang penulis maksudkan di sini adalah menanamkan rasa kebersamaan dan rasa berbagi melalui kegiatan bersama, kegiatan yang melibatkan semua warga sekolah. Adapun hal-hal yang dilakukan dalam membangun budaya kerja sama seperti yang dikemukakan oleh wakasek kurikulum yaitu: "budaya kerja sama yang kami bangun di sekolah ini pada dasarnya juga untuk membangun karaktek kepekaan peserta didik dengan melakukan bentuk kegiatan baksos, PHBN, PORSENI, dan Ekskul. ${ }^{18,}$

Lebih dari itu wakasek kesiswaan memperjelas bentuk kegiatan budaya kerja sama yang dibangun di SMA Negeri 3 Palu yaitu:

1. Latihan bola kaki

2. Latihan basket

3. Latihan paskibra

4. Latihan pramuka

5. Latihan PMR

6. Latihan pecinta alam

7. Latihan theater

8. Latihan voly ball putra

9. Latihan voly ball putri

10. Latihan takraw

11. Latihan debat bahasa Inggris

12. Latihan Karate

13. Latihan Silat

14. Latihan Taekwondo

15. Kegiatan wiyata Mandala/ wawasan kebangsaan / kelas

16. Kegiatan bakti sosia dan MPK

17. Kegiatan keagamaan

18. Bimbingan olimpiade. ${ }^{19}$

\footnotetext{
${ }^{18}$ Halimatang, Wakasek Kurikulum SMA Negeri 3 Palu, "Wawancara” Ruang Wakasek Kurikulum, tanggal 26 September 2019

${ }^{19}$ Haeruddin, Wakasek Kesiswaan SMA Negeri Palu, "Wawancara”, Ruang Wakasek, tanggal 26 September 2019
} 
Dari hasil wawancara tersebut dapat diketahui bahwa bentuk budaya kerja sama yang dibangun di SMA Negeri 3 Palu dari sekian banyak tersebut tentunya sebagai wadah penyaluran minat dan bakat peserta didik dalam mengembanglkan potensi dirinya yang dilakukan melalui kerja sama. Peserta didik terlatih untuk bagaimana caranya bersosialisasi dengan teman sebaya melalui pengawasan dan bimbingan guru. Rasa reeligi yang tinggi dalam lingkungan sekolah membuat SMA Negeri 3 Palu lebih berkualitas dengan tidak membedakan status kemasyarakatan peserta didik, yang kemudian membuahkan rasa saling menghargai satu sama lain.

Hal tersebut juga dikemukakan seorang siswa:

Bentuk kerja sama di sekolah ini dapat kami rasakan baik itu melalui kegiatan ekskul maupun kepada pribadi masing-masing yang kemudian kami saling menghargai baik interen umat beragama maupun antar umat beragama. Bahkan rasa sadar kebersihan lingkungan yang kami dapat di sekolah terbawa sampai lingkungan luar sekolah. ${ }^{20}$

Selain menumbuh kembangkan kerja sama dan memiliki rasa kesetiakawanan yang baik antar peserta didik, peserta didik juga menjalin kerja sama dan hubungan harmonis kepada guru dan kepala sekolah. Hal ini pun sesuai dengan penuturan siswa:

Sejauh ini komunikasi kami dengan guru berjalan dengan baik, menghormati guru, bertatakrama dan salam bila bertemu sudah menjadi budaya yang tidak bisa lepas dalam keseharian dan interaksi kami. Begitupun hubungan kami dengan kepala sekolah, dan warga sekolah lainnya cukup baik. $^{21}$

Begitu pula Kepala Tata Usaha SMA Negeri 3 Palu menuturkan:

Hubungan kerjasama atau kordinasi di sekolah ini terjalin dengan baik, baik KTU terhadap guru, terhadap siswa sampai kepada hubungan kepada kepala sekolah.Ini semua tidak terlepas dari kepemimpinan kepala sekolah yang bagus, yang mengajarkan semua warga sekolah agar selalu memperhatikan kordinasi dan komunikasi agar seluruh aktifitas sekolah lebih terarah". ${ }^{2222}$

Dari keseluruhan bentuk budaya kerja sama (team work) yang dibangun di SMA Negeri 3 Palu semuanya itu tidak terlepas dari tuntunan agama yang mengajarkan kemandirian dan musyawarah, kerja sama, tolong-menolong yang mengarah kepada kemaslahatan bersama untuk mencapai suatu tujuan khususnya pembentukan karakter peserta didik.

3. Budaya Kepemimpin (leadhership)

\footnotetext{
${ }^{20}$ Dewi Safitri, Siwa SMA Negeri 3 Palu, "Wawancara", Taman Sekolah SMA Negeri 3 Palu, tanggal 26 September 2019

${ }^{21}$ Laura Fouriana, siswi kelas X D SMA Negeri 3 Palu, "Wawancara”, Taman Sekolah, tanggal 26September 2019

22 Jefri, KTU SMA Negeri 3 Palu, "Wawancara”, Ruang KTU, tanggal 26September 2019
} 
Budaya kepemimpinan yang dimaksud disini adalah menanamkan jiwa kepemimpinan dan keteladanan sejak dini. Adapun budaya kepemimpinan yang dibangun di SMA Negeri 3 Palu sesuai hasil wawancara penulis dengan beberapa informan sebagaimana hasil wawancara, yaitu:

Budaya kepemimpinan yang kami terapkan di sekolah ini meliputi budaya kerja keras, cerdas, ikhlas, mandiri dan bertanggung jawab, biaya disiplin, OSIS, ceramah umum, upacara bendera, olah raga, latihan dasar kepemimpinan dan yang terkait dengan bentuk kegiatan ekstra kurikuler seperti yang sudah dijelaskan diatas serta peduli lingkungan sebagaimana visi sekolah SMA Negeri 3 Palu. ${ }^{23}$

Lebih dari itu wakasek Kesiswaan mempertegas bahwa" budaya kepemimpinan yang ditanamkan kepada peserta didik diupayakan sebagai media menumbuh kembangkan semangat dan rasa tanggung jawab dalam mewujudkan visi sekolah, selain itu tentunya yang terpenting adalah agar pesrta didik memiliki jiwa kepemimpinan yang berguna bagi agama, bangsa dan religi." 24

Dari hasil wawancara tersebut dapat dilihat bahwa budaya kepemimpinan dengan bentuk-bentuk kegiatannya diatas pada dasarnya juga untuk membentuk karakter peserta didik. Hasil wawancara dengan wakasek kesiswaan menunjukan bahwa budaya yang budaya yang diterapkan baik itu tata tertib maupun yang lainnya, tidak terlepas dari landasan religi yang merupakan tuntunan keagamaan dan hal ini pun juga tidak terlepas dari kode etik siswa-siswi yang yang selama ini menjadi benteng diri dalam bertindak.

\section{PEMBAHASAN}

Tujuan pendidikan budaya dan karakter bangsa adalah mengembangkan potensi kalbu, nurani, afektif peserta didik `sebagai manusia dan warga negara yang memiliki nilai-nilai budaya dan mengembangkan kebiasaan dan perilaku peserta didik yang terpuji dan sejalan dengan nilai-nilai universal dan tradisi budaya bangsa yang religius, menanamkan jiwa kepemimpinan dan tanggung jawab peserta didik sebagai generasi penerus bangsa.Mengembangkan kemampuan peserta didik menjadi manusia yang mandiri, kreatif, berwawasan kebangsaan, mengembangkan lingkungan kehidupan sekolah sebagai lingkungan belajar yang aman, jujur, penuh kreativitas dan persahabatan.

Adapun nilai-nilai yang menjadi acuan dan masuk dalam tata tertib sekolah adalah sebagai berikut:

1. Menjunjung tinggi panca satya

2. Hormat kepada orang tua

3. Hormat kepada guru/ tata usaha

4. Pantang menyontek

5. Pantang menipu

${ }^{23}$ Halimatang, Wakasek Kurikulum SMA Negeri 3 Palu, "Wawancara” Ruang Wakasek Kurikulum, tanggal 26 September 2019

${ }^{24}$ Salim, Wakasek Kesiswaan SMA Negeri Palu, "Wawancara", Ruang Wakasek, tanggal 26 September 2019 
6. Pantang mencuri

7. Pantang berkelahi

8. Pantang berbuat Asusila

9. Pantang menkonsumsi narkoba ${ }^{25}$

Mulai tahun pelajaran 2011 dan sampai saat ini, seluruh tingkat pendidikan di Indonesia harus memasukkan pendidikan karakter sesuai amanat dalam kurikulum ( $\mathrm{K}$ 13), karena pendidikan karakter merupakan ruh dari proses pembelajaran di era globalisasi atau era disrupsi 4.0 saat ini.

Dalam pandangan Islam pendidikan karakter sebenarnya telah dipraktekkan seiring dengan diutusnya Nabi Muhammad saw. sebagai Nabi dan Rasul akhir zaman. Dengan penjelasan di atas, maka hendaknya setiap sekolah dapat mengembangkan nilai-nilai budaya karakter yang sesuai dengan ciri khas dan visi misinya masing-masing. Suatu sekolah bisa saja memiliki kegiatan yang sama dalam mengimplementasi budaya karakter, namun ruh dari karakter tersebut sejauh mana dapat terjiwai oleh warga sekolah tentunya berbeda-beda.

Dari hasil wawancara dengan beberapa informan di atas dapat disimpulkan bahwa dalam membangun nilai-nilaibudaya sekolah baik budaya sekolah religius, budaya kerja sama, dan budaya kepemimpinan di SMA Negeri 3 Palu, keseluruhannya tidak terlepas dari nilai-nilai karakter dan peran pengembangan pendidikan Agama Islam, dalam mengajarkan dan menanamkan pendidikan agama Islam tidak hanya sekedar pada jam pelajaran agama saja, tetapi lebih dikembangkan dalam kehidupan sehari-hari. Adapun untuk lebih jelasnya, kegiatan yang termasuk budaya religius, budaya kepemimpinan dan kerja sama yang sudah terjadwal secara berkesinambungan.

\section{KESIMPULAN}

Berdasarkan uraian yang telah dikemukakkan di atas, maka dapat disimpulkan bahwa pengembangan budaya sekolah di SMA Negeri 3 Palu, cukup signifikan dari tahun ke tahun.Keberadaan warga sekolah yang multi religius, multi etnis dan multikultur mengantarkan warga sekolah ini dapat berinteraksi dan mengembangkan bakat siswa siswinya secaramasif dan melahirkan karakter yang tangguh dan berbakat. Ada tiga komponen budaya sekolah yang dikembangkan oleh komponen sekolah yaitu : pertama, budaya religius, yaitu budaya menanamkan perilaku atau tatakrama yang tersistematis dalam pengamalan agamanya masingmasing sehingga terbentuk kepribadian dan sikap yang baik (akhlaqul Karimah) serta disiplin dalam berbagai hal, baik di dalam kelas maupun di luar kelas. Kedua, budaya tim work adalah menanamkan rasa kebersamaan dan rasa sosial melalui kegiatan bersama.Bentuk Kegiatan Masa Orientasi Sekolah (MOS), Kunjungan Industri, Parents Day, bakti sosial, Teman Asuh, Sport And Art, Kunjungan Museum, Pentas Seni, Studi banding, Ekskul, Labs Channel, Labs TV, Labs Care, Pelepasan Siswa, Seragam Sekolah, Majalah Sekolah, Potency Mapping. Ketiga, Budaya

${ }^{25}$ Haeruddin, Wakasek Kesiswaan SMA Negeri Palu, "Wawancara", Ruang Wakasek, tanggal 26 September 2019 
Kepemimpinan (Leadhership), adalah menanamkan jiwa kepemimpinan dan keteladanan dari sejak dini. Bentuk Kegiatan, Career Day; budaya kerja keras, cerdas dan ikhlas, budaya Kreatif; Mandiri \& bertanggung jawab, Budaya disiplin, lintas juang OSIS, Ceramah Umum, upacara bendera, Olah Raga Jumat Pagi, Studi Kepemimpinan Siswa, LKMS, OSIS.Dengan motto yang disepakati bersama oleh sekolah misalnya kreatif dan berprestasi, akan menjadikan sekolah itu unggul dan berkualitas. Nilai-nilai yang dibangun dalam budaya sekolah di SMA Negeri 3 Palu adalah nilai-nilai sosial budaya yang mana masyarakat tidak lagi menganggap dan memiliki paradigma lama dengan meyerahkan urusan pendidikan dan permasalahan sekolah kepada pihak sekolah saja, namun masyarakat ikut bertanggung jawab dan menjadi bagian dari warga sekolah sehingga memiliki school cultur yang berkarakter dan kokoh. Adapun nilai-nilai yang terkandung dan dipraktekan oleh siswa dalam kesehariannya adalahmenjunjung tinggi panca satya, hormat pada orang, hormat terhadap guru, tata usaha dan yang dianggap lebih tua, pantang menyontek, jujur, tidak mencuri, tidak berkelahi, tidak berbuat asusila, tidak mengkonsumsi narkoba. Termasuk 18 nilai-nilai pendidikan karakter.

\section{DAFTAR PUSTAKA}

Abdul Ghofir \&Zuhairini, Metodologi Pendidikan Agama Islam.Malang: UM, 2004 Abdul, Mujib. Kepribadian dalam Psikologi Islam.Jakarta: PT Raja Grafindo Persada. 2006

Ahmad, Dadang Metodologi penelitian Agama.Bandung; Pustaka Setia, 2000 Daulay, Haydar Putra. Pemberdayaan Pendidikan Islam di Indonesia. Jakarta: PT Rineka Cipta, 2009

Digest, Eric. School Culture.Http:// www.ed. Gov/databases Hamka.Kurikulum dan Realitas Sosial.Cet; 1, Palu: Yamiba, 2009

Wijaya.http://wijayalabs.blogdetik.com/tag/budaya-sekolah/html

Kusuma.http://education-mantap.blogspot.eom12010/07/budaya-sekolah.html

Jurnal Penelitian kependidikan, Pengembangan Budaya Sekolah Berprestasi: Studi Tentang Penanaman Nilai dan Etos Berprestasi di SMA Karangturi, vol.3, No.2, 2011

Koeatjtaningrat.Kebudayaan, Mentalitet dan Pembangunan, Jakarta: Gramedia, 1974 Kompri, Manajemen Sekolah: Teori dan Praktek. Bandung: Alfabeta

Lexy J.Moleong.Metodologi Penelitian Kualitatif.Bandung: PT. Remaja Rosdakarya, 2001

Lickona, Thomas, Education For Character : How Our Shcools Can Teach Respect and Responsibility, The journal Of Moral Education dalam Terjemahan Mendidik Untuk Membentuk Karakter: Bagaimana Sekolah Dapat Mengajarkan Sikap Hormat dan Tanggung Jawab, Jakarta : Bumi Aksara, 2015

Milles, Mattew B. Quantitatif Data Analisis. Diterjemahkan oleh Tjep Rohandi, analisis data kualitatifJakarta: UI Press, 1992 
Madina Sofyan. 2010. Eksistensi Budaya Sekolah (Upaya Mencipta dan Meningkatkan Mutu Pendidikan). Laporan tidak diterbitkan. Makassar: UNM Makassar Muhaimin, Nuansa Baru Pendidikan Islam. Jakarta: PT. Raja Grafindo Persada, 2006 